\title{
ARTICLE
}

Received 10 Oct 2014 | Accepted 10 Jun 2015 | Published 27 Jul 2015

DOI: $10.1038 /$ ncomms 8799

OPEN

\section{How and when plume zonation appeared during the 132 Myr evolution of the Tristan Hotspot}

Kaj Hoernle ${ }^{1,2}$, Joana Rohde ${ }^{1}$, Folkmar Hauff ${ }^{1}$, Dieter Garbe-Schönberg ${ }^{2}$, Stephan Homrighausen ${ }^{1}$, Reinhard Werner ${ }^{1} \&$ Jason P. Morgan ${ }^{3}$

Increasingly, spatial geochemical zonation, present as geographically distinct, subparallel trends, is observed along hotspot tracks, such as Hawaii and the Galapagos. The origin of this zonation is currently unclear. Recently zonation was found along the last $\sim 70 \mathrm{Myr}$ of the Tristan-Gough hotspot track. Here we present new $\mathrm{Sr}-\mathrm{Nd}-\mathrm{Pb}-\mathrm{Hf}$ isotope data from the older parts of this hotspot track (Walvis Ridge and Rio Grande Rise) and re-evaluate published data from the Etendeka and Parana flood basalts erupted at the initiation of the hotspot track. We show that only the enriched Gough, but not the less-enriched Tristan, component is present in the earlier (70-132 Ma) history of the hotspot. Here we present a model that can explain the temporal evolution and origin of plume zonation for both the Tristan-Gough and Hawaiian hotspots, two end member types of zoned plumes, through processes taking place in the plume sources at the base of the lower mantle.

\footnotetext{
${ }^{1}$ GEOMAR Helmholtz Centre for Ocean Research Kiel, Wischhofstrasse 1-3, 24148 Kiel, Germany. ${ }^{2}$ CAU Kiel University, Institute of Geosciences, LudewigMeyn-Strasse 10, D-24118 Kiel, Germany. ${ }^{3}$ Royal Holloway, University of London, Department of Earth Sciences, Egham Hill, Egham TW20 OEX, UK. Correspondence and requests for materials should be addressed to K.H. (email: khoernle@geomar.de).
} 
A lthough it has been proposed that some plumes have had constant compositions through time, such as the Louisville $^{1}$ and Kerguelen ${ }^{2,3}$, spatial geochemical zonation has been found in a variety of hotspot tracks in the Pacific Ocean. These include the Galapagos ${ }^{4-7}$, Hawaiian ${ }^{8,9}$, Samoan ${ }^{10}$, Marquesan $^{10,11}$ and Society ${ }^{12}$ hotspot tracks, which are believed to be located at the border of the large, lower mantle, low shear-wave velocity province (LLSVP) beneath the southern Pacific $9,10,12,13$. The longevity of plume zonation is variable for the different Pacific hotspots. It can be traced for $15-20 \mathrm{Myr}$ along the Galapagos hotspot $\operatorname{track}^{6,7}$, for $\sim 4 \mathrm{Myr}$ along the Society hotspot track ${ }^{12,14}$, for $\sim 5.5 \mathrm{Myr}$ along the Marquesas ${ }^{11,15}$ and for up to $2 \mathrm{Myr}$ along the Samoan Islands ${ }^{10,14,16}$. The coexistence of the geochemically distinct Loa and Kea trends of the Hawaiian mantle plume has been traced for the last $5 \mathrm{Myr}$ along the island chain'. Little evidence exists for the presence of the Loa component in the Hawaiian seamounts, located west of the Hawaiian Islands and only the Kea component has been recognized so far in the Emperor Seamounts and older accreted Hawaiian complexes in Kamchatka ${ }^{17}$. To address questions concerning the longevity of plume zonation and how it originates, we investigate the entire history of the Tristan-Gough hotspot here and compare it with what is known about the history of the Hawaiian hotspot.

The Tristan-Gough hotspot track (Fig. 1) represents the classic evolution of a hotspot ${ }^{18}$ with active volcanic islands at its young end and flood basalt provinces at its older end. It has been termed one of the seven hotspots most likely to be derived from the lowermost mantle from a 'primary' plume $^{19}$ with its base currently located at the margin of the African LLSVP ${ }^{20,21}$. The emplacement of a Tristan-Gough plume head at the base of the Gondwana lithosphere caused massive volcanism forming the Parana (eastern South America) and Etendeka (western Africa) flood basalts at $\sim 132 \mathrm{Ma}^{22}$ and may have contributed to the breakup of Africa from South America and the formation of the South Atlantic Ocean basin ${ }^{23}$. As the Atlantic opened,

the ridge-centred plume tail formed the Walvis Ridge on the African Plate and the Rio Grande Rise (possibly underlain by a thinned continental block) on the South American Plate. As the South Atlantic mid-ocean ridge drifted westwards away from the plume tail $\sim 50-60 \mathrm{Ma}$, the hotspot became intraplate forming the Guyot Province, consisting of separate volcanic tracks leading to the active volcanic islands of Tristan da Cunha and Gough ${ }^{24}$.

Recently published $\mathrm{Sr}-\mathrm{Nd}-\mathrm{Hf}-\mathrm{Pb}$ isotope data of samples from the Tristan-Gough hotspot track reveal that bilateral chemical zonation can be traced from the Tristan da Cunha and Gough island groups along the Tristan and Gough subtracks for the last $\sim 70$ Myr to the southwestern (SW) end of the Walvis Ridge ${ }^{13}$ (Fig. 1). The enriched Gough domain exhibits higher ${ }^{207} \mathrm{~Pb} /{ }^{204} \mathrm{~Pb}$ for a given ${ }^{206} \mathrm{~Pb} /{ }^{204} \mathrm{~Pb}$ and extends to lower ${ }^{143} \mathrm{Nd} /{ }^{144} \mathrm{Nd}$ and ${ }^{176} \mathrm{Hf} /{ }^{177} \mathrm{Hf}$ ratios and generally higher ${ }^{87} \mathrm{Sr} /{ }^{86} \mathrm{Sr}$ ratios compared with the more depleted (less enriched) Tristan domain. The domains form distinct fields on the uranogenic $\mathrm{Pb}$ isotope diagram (Fig. 2a). Published geochemical data are, however, insufficient to establish chemical zonation beyond $70 \mathrm{Ma}$.

Here we present new $\mathrm{Sr}-\mathrm{Nd}-\mathrm{Hf}-\mathrm{Pb}$ double spike (DS) isotope data from additional samples from the Guyot Province (obtained during R/V Akademik Kurchatov, AII-93 Atlantis II, ANT-XXIII/ 5 Polarstern, VM29 Vema, 51 S.A. Agulhas and SO233 Sonne cruises) and Deep Sea Drilling Programme (DSDP) Sites 525A, 527 and 528 at the SW end of the Walvis Ridge to test whether this part of the hotspot track is indeed zoned. More importantly we present new data from dredge (VM29 Vema, CIRCE Argo, AII-93 Atlantis II, CH19 Jean Charcot, WALDAA-002 Jean Charcot, RC11 Robert D. Conrad and SO233 Sonne cruises) and DSDP Leg 72 drill samples from the older part of the hotspot track (central and northeast Walvis Ridge and Rio Grande Rise) to determine whether the zonation can be traced further back in time, that is, going northeast along the hotspot track. Finally, we

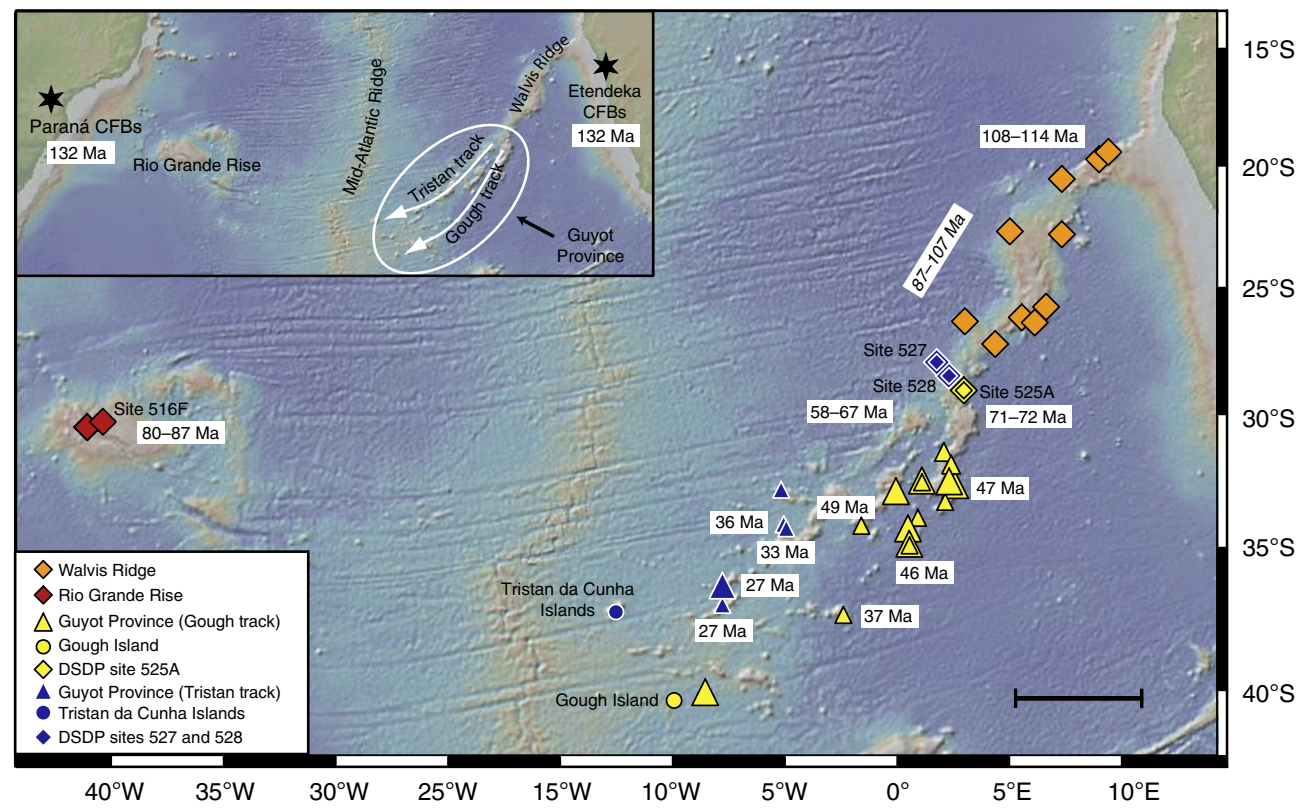

Figure 1 | Bathymetric map of the South Atlantic Ocean and its margins showing the Tristan-Gough hotspot track. The map shows the Tristan-Gough hotspot track including the $\sim 132 \mathrm{Myr}$ (ref. 22) old Etendeka and Parana continental flood basalt provinces, the Rio Grand Rise and Walvis Ridge (both within the age range $\sim 60-115 \mathrm{Ma}$ ), the Guyot Province at the southwestern end of the Walvis Ridge containing the Tristan da Cunha and Gough Island groups $(\sim 0-60 \mathrm{Ma})^{24}$. Ages for late-stage volcanism are not shown. Age range in italics (87-107 Ma) is estimated using a spatial age progression equation ${ }^{24}$. Sample locations are denoted by symbols: large symbols this study and small symbols as reported in ref. 13. Source of base map is http:// www.geomapapp.org. All sites are from the Deep Sea Drilling Project. The scale bar in the lower right hand corner indicates a distance of $\sim 500 \mathrm{~km}$. 


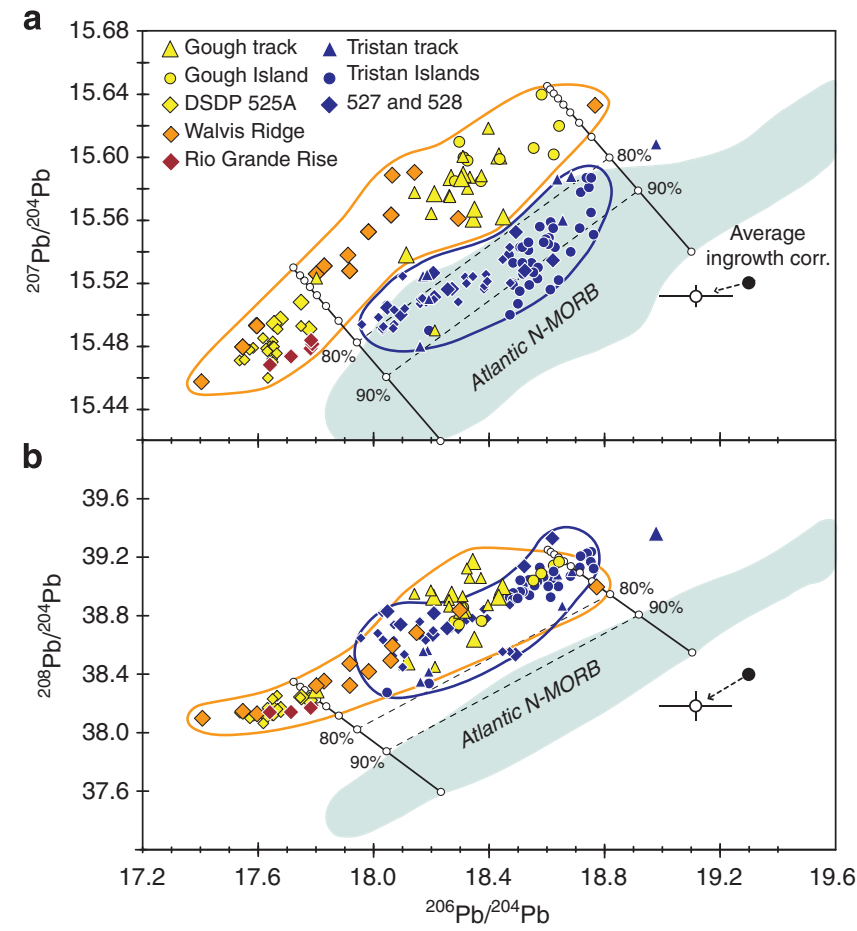

Figure 2 | The $>70$ Ma Tristan-Gough hotspot track lavas have Goughtype isotopic compositions. On the (a) ${ }^{206} \mathrm{~Pb} /{ }^{204} \mathrm{~Pb}$ versus ${ }^{207} \mathrm{~Pb} /{ }^{204} \mathrm{~Pb}$ (uranogenic $\mathrm{Pb}$ ) isotope diagram, older hotspot lavas ( $>70 \mathrm{Ma}$ ) fall solely within the Gough field of ref. 13. Even though they are completely separated on the uranogenic $\mathrm{Pb}$ isotope diagram, the Tristan and Gough fields completely overlap on the (b) ${ }^{206} \mathrm{~Pb} /{ }^{204} \mathrm{~Pb}$ versus ${ }^{208} \mathrm{~Pb} /{ }^{204} \mathrm{~Pb}$ (thorogenic $\mathrm{Pb}$ ) isotope diagram, indicating that the Tristan compositions cannot simply be explained by mixing of Gough compositions with Atlantic MORB.

Modelling shows that addition of 70 to $>90 \%$ Atlantic N-MORB to Gough can explain the shift in Tristan to N-MORB in (a), but would require the Tristan field to be shifted towards Atlantic N-MORB in (b), for example, extending beyond the $>90 \%$ mixing line towards N-MORB as in (a). Pb concentrations used for the mixing calculations are 0.57 p.p.m. for the MORB end members (based on average of global N-MORB ${ }^{62}$ ) and 3.2 p.p.m. for the Gough end members (average of Gough samples with $\mathrm{MgO}>1$ wt.\%) (Supplementary Dataset 1). Changing the assumed concentrations for Gough and MORB end members will simply shift the mixing percentages, but mixing of Gough and Atlantic N-MORB will still require Tristan to be shifted towards $\mathrm{N}-\mathrm{MORB}$ compared with Gough on the thorogenic $\mathrm{Pb}$ isotope diagram. To compare isotope data of samples ranging in age between $\sim 0-115 \mathrm{Ma}$, we use the measured compositions, assuming that the parent-daughter ratios were not significantly fractionated during melting or subsequent

differentiation. The 'average ingrowth corr.' and associated $1 \sigma$ variation is the average correction needed for radiogenic ingrowth for the plotted samples (Supplementary Dataset 1). Since the age correction moves the data sub parallel to the boundary between the Gough and Tristan fields in (a), radiogenic ingrowth does not cause overlap between Gough and Tristan samples and therefore does not affect the classification of the samples. Analytical errors of data (Supplementary Dataset 1) in these and all subsequent isotope diagrams are smaller than symbol size. Numbers in the legend refer to DSDP Sites (Fig. 1). Atlantic MORB from PetDB (http://www.earthchem.org/petdb) and additional Tristan-Gough data from GEOROC (http://georoc.mpch-mainz.gwdg.de/georoc/).

evaluate published data from the Etendeka and Parana flood basalts to assess the composition of the plume during its earliest history. These results are used to establish a model for the entire temporal (last $132 \mathrm{Myr}$ ) geochemical evolution of the TristanGough hotspot. Finally, we compare the evolution of the Tristan and Hawaiian plumes and evaluate the origin of geochemical zonation in both plumes.

\section{Results}

Isotopic composition of Tristan-Gough hotspot track lavas. The new $\mathrm{Sr}-\mathrm{Nd}-\mathrm{Hf}-\mathrm{Pb}$ isotope data are presented in (Table 1). We report details about the samples, the major and trace element data and isotope data with errors in Methods and Supplementary Dataset 1. The $\mathrm{Sr}-\mathrm{Nd}-\mathrm{Hf}-\mathrm{Pb}$ isotope data of the new samples from the Guyot Province and DSDP Sites 525A, 527 and 528 at the SW end of the Walvis Ridge confirm the spatial geochemical zonation of the $\leq 70 \mathrm{Ma}$ hotspot track proposed by (ref.13; Fig. 2a). The data from the older ( $>70 \mathrm{Ma}$ ) hotspot track, central and northeast portion of the Walvis Ridge and the Rio Grande Rise ${ }^{24}$, plot exclusively within the Gough field. They also completely cover the range of the $\leq 70 \mathrm{Ma}$ Gough track, showing that there is no systematic temporal change in the Gough source through time. The Rio Grande Rise samples and some samples from the Walvis Ridge are isotopically as enriched as DSDP Site 525A: the enriched mantle one (EMI) end member in the South Atlantic ${ }^{25,26}$.

Sr and Nd isotopes of Etendeka and Parana flood basalts. Evaluating the composition of the mantle plume head linked to the $132 \mathrm{Ma}$ Parana-Etendeka flood basalt event is difficult because of potential interaction of melts with the continental lithosphere (both crust and mantle), which overall has a geochemically enriched composition in comparison with oceanic lithosphere. Lavas and dykes associated with the $132 \mathrm{Ma}$ volcanic event range from pricritic and tholeiitic basalts through highly silica-undersaturated nephelinites to highly evolved rhyolites through phonolites. Intrusive equivalents range from gabbros to granites to syenites. These magmatic rocks show an extremely large range in measured ${ }^{87} \mathrm{Sr} /{ }^{86} \mathrm{Sr}$ of $\sim 0.703-0.743$ (with one sample having 0.924 ) and ${ }^{143} \mathrm{Nd} /{ }^{144} \mathrm{Nd}$ of $\sim 0.5117-0.5129$ (Figs 3 and $4 \mathrm{a}$ ). On plots of $\mathrm{MgO}$ versus ${ }^{87} \mathrm{Sr} /{ }^{86} \mathrm{Sr}$ and ${ }^{143} \mathrm{Nd} /$ ${ }^{144} \mathrm{Nd}$ isotope ratios (Fig. 3), the most magnesium-rich samples have the lowest ${ }^{87} \mathrm{Sr} /{ }^{86} \mathrm{Sr}$ and highest ${ }^{143} \mathrm{Nd} /{ }^{144} \mathrm{Nd}$ isotope ratios and show the least variation. With decreasing $\mathrm{MgO}$, the range in ${ }^{87} \mathrm{Sr} /{ }^{86} \mathrm{Sr}$ and ${ }^{143} \mathrm{Nd} /{ }^{144} \mathrm{Nd}$ increases systematically with ${ }^{87} \mathrm{Sr} /{ }^{86} \mathrm{Sr}$ extending to higher and ${ }^{143} \mathrm{Nd} /{ }^{144} \mathrm{Nd}$ to lower ratios. If only samples with $\mathrm{MgO} \geq 11$ wt.\% ( $\mathrm{Sr}>600$ p.p.m.; Supplementary Fig. 1) are considered, for example, the range in ${ }^{87} \mathrm{Sr} /{ }^{86} \mathrm{Sr}$ $(0.7044-0.7091)$ and ${ }^{143} \mathrm{Nd} /{ }^{144} \mathrm{Nd}(0.51240-0.51288)$ is considerably reduced. The much larger range present in the more evolved compositions most likely reflects derivation through continental lithospheric melting or through assimilation of such melts by differentiated mantle melts. Extensive feldspar fractionation in many highly evolved melts reduces the $\mathrm{Sr}$ concentration to very low values, whereas $\mathrm{Rb}$ continues to be incompatible in the melts and thus its concentration increases, resulting in very high $\mathrm{Rb} / \mathrm{Sr}$ ratios. Radiogenic ingrowth in the evolved rocks with very high $\mathrm{Rb} / \mathrm{Sr}$ ratios contributes to the elevated ${ }^{87} \mathrm{Sr} /{ }^{86} \mathrm{Sr}$ ratios. Although the ${ }^{143} \mathrm{Nd} /{ }^{144} \mathrm{Nd}$ of the mafic $(\mathrm{MgO} \geq 11$ wt.\%) flood basalts is similar to the oceanic Tristan-Gough track rocks (Fig. 4a), the ${ }^{87} \mathrm{Sr} /{ }^{86} \mathrm{Sr}$ in some mafic samples extends to higher ratios, which can be explained by small amounts of assimilation of crust with very radiogenic ${ }^{87} \mathrm{Sr} /{ }^{86} \mathrm{Sr}$ (for example, some crustal rocks have extreme ${ }^{87} \mathrm{Sr} /{ }^{86} \mathrm{Sr}$ up to 1.18 ) and/or through melting of enriched portions of the lithospheric mantle with radiogenic $\mathrm{Sr}$ and $\mathrm{Pb}$ isotope ratios ${ }^{27}$.

$\mathrm{Pb}$ isotopes of Etendeka and Parana flood basalts. In contrast to ${ }^{87} \mathrm{Sr} /{ }^{86} \mathrm{Sr}$ and ${ }^{143} \mathrm{Nd} /{ }^{144} \mathrm{Nd}$ where both upper and lower crustal interaction generally cause an increase in ${ }^{87} \mathrm{Sr} /{ }^{86} \mathrm{Sr}$ and decrease 
Table 1 | Sr-Nd-Hf-Pb double-spike isotope data for Tristan-Gough hotspot track samples.

\begin{tabular}{l} 
Sample \\
\hline Tristan Track \\
AK-1695-6 \\
Gough track \\
SO233 DR3-1 \\
All-93-11-8 \\
PS69/420-1-DR 21-1 \\
PS69/423-1-DR 25-4 \\
PS69/424-1-DR 26-1 \\
V29-9-1 \\
AG51-6-5 \\
AG51-7-1 \\
AG51-7-2
\end{tabular}

Walvis Ridge Gough composition

\begin{tabular}{|c|c|c|c|c|c|c|c|c|c|}
\hline CH19 DR3-2 & 114 & -19.37 & 9.33 & 0.705919 & 0.512464 & 17.9161 & 15.5279 & 38.3254 & 0.282724 \\
\hline $\mathrm{CH} 19$ DR4-1 & 113 & -19.85 & 9.02 & 0.705709 & 0.512342 & 17.5458 & 15.4796 & 38.1510 & 0.282668 \\
\hline $\mathrm{CH} 19$ DR4-2 & 112 & -19.85 & 9.02 & 0.705607 & 0.512387 & 17.5932 & 15.4933 & 38.1276 & 0.282683 \\
\hline WALDA-002-CH19-DR4-03 & 113 & -19.85 & 9.02 & 0.705574 & 0.512397 & 17.5942 & 15.4930 & 38.1328 & 0.282675 \\
\hline SO233 DR84-2 & 114 & -20.35 & 7.64 & 0.706235 & 0.512308 & 17.4079 & 15.4574 & 38.0939 & - \\
\hline SO233 DR66-1 & 107 & -22.72 & 7.58 & 0.704928 & 0.512612 & 18.2968 & 15.5608 & 38.8369 & - \\
\hline SO233 DR71-1 & 101 & -22.67 & 5.13 & 0.704192 & 0.512472 & 18.7701 & 15.6325 & 38.9967 & - \\
\hline SO233 DR62-1 & 96 & -25.85 & 6.62 & 0.705231 & 0.512519 & 18.1463 & 15.5903 & 38.6825 & - \\
\hline SO233 DR34-1-A & 87 & -26.29 & 3.47 & 0.704735 & 0.512585 & 17.9160 & 15.5376 & 38.4723 & - \\
\hline V29-11-1 & 85 & -26.15 & 5.58 & 0.704724 & 0.512503 & 17.9811 & 15.5529 & 38.4227 & 0.282774 \\
\hline CIR 139D-2 & 85 & -26.45 & 5.89 & 0.704845 & 0.512496 & 17.8002 & 15.5259 & 38.3248 & 0.282725 \\
\hline CIR 139D-3 & 85 & -26.45 & 5.89 & 0.704853 & 0.512509 & 17.8275 & 15.5310 & 38.3558 & 0.282723 \\
\hline Walvis III DR04-35 & 79 & -27.26 & 4.39 & 0.704678 & 0.512649 & 18.0587 & 15.5635 & 38.4937 & 0.282841 \\
\hline DSDP Leg 74 525A 53 2W 91-102 & 71 & -29.07 & 2.99 & 0.704909 & 0.512516 & 17.7478 & 15.5081 & 38.2496 & 0.282756 \\
\hline DSDP Leg 74 525A 56 2W 128-134 & 71 & -29.07 & 2.99 & 0.704771 & 0.512490 & 17.6759 & 15.4972 & 38.1620 & 0.282748 \\
\hline DSDP Leg 74 525A 57 5W 141-148 & 72 & -29.07 & 2.99 & 0.704841 & 0.512489 & 17.6544 & 15.4945 & 38.1603 & 0.282747 \\
\hline DSDP Leg 74 525A 63 2W 59-78 & 72 & -29.07 & 2.99 & 0.705061 & 0.512431 & 17.7753 & 15.4910 & 38.2252 & 0.282702 \\
\hline \multicolumn{10}{|l|}{ Valvis Ridge Tristan composition } \\
\hline DSDP Leg 7452741 W 47-63 & 67 & -28.04 & 1.76 & 0.704144 & 0.512726 & 18.2048 & 15.5267 & 38.6715 & 0.282987 \\
\hline DSDP Leg 7452741 5W 95-105 & 67 & -28.04 & 1.76 & 0.703608 & 0.512901 & 18.4908 & 15.5527 & 38.5336 & 0.283060 \\
\hline DSDP Leg 7452743 4W 59-73 & 67 & -28.04 & 1.76 & 0.704547 & 0.512611 & 18.6188 & 15.5347 & 39.3297 & 0.282867 \\
\hline DSDP Leg 7452744 4W 59-72 & 67 & -28.04 & 1.76 & 0.704427 & 0.512617 & 18.5224 & 15.5281 & 39.1353 & 0.282866 \\
\hline DSDP Leg 7452842 1W 29-45 & 58 & -28.53 & 2.32 & 0.704744 & 0.512563 & 18.0458 & 15.5046 & 38.8273 & 0.282818 \\
\hline DSDP Leg 7452842 5W 31-46 & 58 & -28.53 & 2.32 & 0.703996 & 0.512771 & 18.2698 & 15.5165 & 38.7332 & 0.283027 \\
\hline DSDP Leg 7452843 2W 80-98 & 67 & -28.53 & 2.32 & 0.704092 & 0.512681 & 18.2553 & 15.5161 & 38.7148 & 0.282920 \\
\hline DSDP Leg 7452845 2W 109-119 & 67 & -28.53 & 2.32 & 0.704285 & 0.512648 & 18.0917 & 15.5001 & 38.7408 & 0.282916 \\
\hline DSDP Leg 7452847 3W 66-80 & 67 & -28.53 & 2.32 & 0.704456 & 0.512634 & 18.2089 & 15.5113 & 38.8174 & 0.282896 \\
\hline \multicolumn{10}{|l|}{ io Grande rise } \\
\hline RC16-11RD 1 & 84 & -30.43 & -36.02 & 0.705578 & 0.512353 & 17.7807 & 15.4787 & 38.1734 & 0.282646 \\
\hline RC16-11RD 2 & 84 & -30.43 & -36.02 & 0.705572 & 0.512344 & 17.7866 & 15.4813 & 38.1861 & 0.282647 \\
\hline RC16-12RD 1 & 84 & -30.43 & -36.02 & 0.705687 & 0.512342 & 17.7822 & 15.4839 & 38.1913 & 0.282616 \\
\hline RC16-12RD 3 & 84 & -30.43 & -36.02 & 0.705952 & 0.512273 & 17.7127 & 15.4736 & 38.1437 & 0.282588 \\
\hline DSDP Leg 72 516F 128 2W 63-84 & 85 & -30.28 & -35.29 & 0.704988 & 0.512543 & 17.6396 & 15.4681 & 38.1425 & 0.282843 \\
\hline
\end{tabular}

Full data, including errors are provided in Supplementary Dataset 1 . Average $2 \sigma$ within run errors refer to the least significant digits and are \pm 5 for ${ }^{87} \mathrm{Sr} /{ }^{86} \mathrm{Sr}, \pm 3$ for ${ }^{143} \mathrm{Nd} /{ }^{144} \mathrm{Nd}, \pm 5$ for ${ }^{176} \mathrm{Hf} /{ }^{177} \mathrm{Hf}$, $\pm 11, \pm 11$ and \pm 33 for ${ }^{206} \mathrm{~Pb} /{ }^{204} \mathrm{~Pb},{ }^{207} \mathrm{~Pb} /{ }^{204} \mathrm{~Pb}$ and ${ }^{208} \mathrm{~Pb} /{ }^{204} \mathrm{~Pb}$, respectively. External $2 \sigma$ errors based on standards measured along with the samples are \pm 13 for ${ }^{87} \mathrm{Sr} /{ }^{86} \mathrm{Sr}, \pm 7 \mathrm{for}{ }^{143} \mathrm{Nd} /{ }^{144} \mathrm{Nd}$, \pm 8 for ${ }^{176} \mathrm{Hf} /{ }^{177} \mathrm{Hf}, \pm 24, \pm 24$ and \pm 61 for ${ }^{206} \mathrm{~Pb} /{ }^{204} \mathrm{~Pb},{ }^{207} \mathrm{~Pb} / 204 \mathrm{~Pb}$ and ${ }^{208} \mathrm{~Pb} /{ }^{204} \mathrm{~Pb}$ respectively ${ }^{87} \mathrm{Sr} /{ }^{86} \mathrm{Sr}$ are the least radiogenic values obtained on dual analysis of $2 \mathrm{~N} \mathrm{HCl}$ leached rock chips at $70^{\circ} \mathrm{C}$ for $1 \mathrm{~h}$ and $6 \mathrm{~N} \mathrm{HCl}$ leached powders at $150^{\circ}$ for 3 days. Ages in bold are from ref. 24 . Ages in italics are either from dated samples from the same site or estimated based on a spatial linear age at $70^{\circ} \mathrm{C}$ for 1 ha equation ${ }^{24}$.

${ }^{143} \mathrm{Nd} /{ }^{144} \mathrm{Nd}$ isotope ratios ${ }^{27}, \mathrm{~Pb}$ isotope ratios do not show good correlations with $\mathrm{MgO}$ or $\mathrm{Pb}$ concentration. The reason in part for the lack of correlation is that the lower crust generally has unradiogenic $\mathrm{Pb}$ isotope ratios, as indicated for example by the composition of granulites from the Namaqua-Natal Belt in South Africa $^{28}$ and diorites derived from lower crustal melting during the Damara Orogen in Namibia ${ }^{29}$, whereas the upper crust extends to more radiogenic $\mathrm{Pb}$ isotope ratios, for example, Khan granodiorites and Kuiseb schists in Namibia ${ }^{30,31}$. On the uranogenic $\mathrm{Pb}$ isotope diagram (Fig. 4b), where the Tristan and Gough domains form distinct fields, the Parana-Etendeka data form an array that completely covers the Gough field but extends to more radiogenic (probably reflecting upper crustal contamination) and less radiogenic (probably reflecting lower crustal contamination) compositions. Some of this variation, for example, the lower trend towards more radiogenic $\mathrm{Pb}$ isotope ratios (Fig. 4b), could also result from contamination within the subcontinental lithospheric mantle, which can have more 


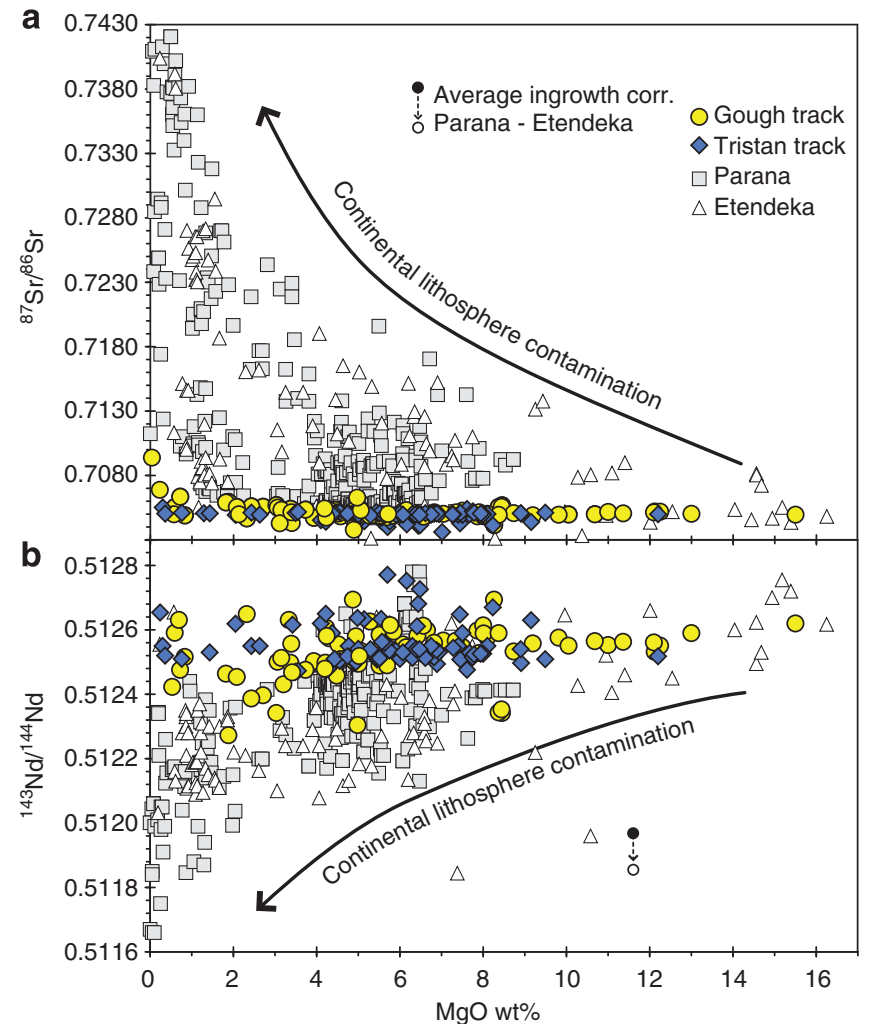

Figure 3 | Evolved Parana and Etendeka continental flood volcanism shows much greater isotopic variation than the oceanic Tristan-Gough hotspot track lavas. On plots of $\mathrm{MgO}$ vs. (a) ${ }^{87} \mathrm{Sr} /{ }^{86} \mathrm{Sr}$ and (b) ${ }^{143} \mathrm{Nd}$ /

${ }^{144} \mathrm{Nd}$, the oceanic lavas have relatively constant composition and unradiogenic ${ }^{87} \mathrm{Sr} /{ }^{86} \mathrm{Sr}$ but radiogenic ${ }^{143} \mathrm{Nd} /{ }^{144} \mathrm{Nd}$ regardless of $\mathrm{MgO}$ content (degree of differentiation). The continental volcanism, however shows a greater range in ${ }^{87} \mathrm{Sr} /{ }^{86} \mathrm{Sr}$ and ${ }^{143} \mathrm{Nd} /{ }^{144} \mathrm{Nd}$ extending to systematically more radiogenic ${ }^{87} \mathrm{Sr} /{ }^{86} \mathrm{Sr}$ and less radiogenic ${ }^{143} \mathrm{Nd} /{ }^{144} \mathrm{Nd}$ with increasing degree of differentiation (decreasing $\mathrm{MgO}$ ). The increasing and substantially greater range in ${ }^{87} \mathrm{Sr} /{ }^{86} \mathrm{Sr}$ and ${ }^{143} \mathrm{Nd} /{ }^{144} \mathrm{Nd}$ for the continental, compared with oceanic, volcanic rocks primarily reflects increasing amounts of assimilation during fractional crystallization of continental lithosphere by some magmas. Radiogenic ingrowth in some of the most evolved silica-saturated samples with very high $\mathrm{Rb} / \mathrm{Sr}$ ratios also contributes to the extremely radiogenic ${ }^{87} \mathrm{Sr} /{ }^{86} \mathrm{Sr}$. Average correction for radiogenic ingrowth for Parana and Etendeka is based on $498\left({ }^{87} \mathrm{Sr} /{ }^{86} \mathrm{Sr}\right.$ ) and $280\left({ }^{143} \mathrm{Nd} /{ }^{144} \mathrm{Nd}\right)$ analyses for which parent/daughter ratios are available. See Supplementary Dataset 5 and additional data from GEOROC (http://georoc.mpch-mainz.gwdg.de/georoc/).

radiogenic $\mathrm{Sr}$ and $\mathrm{Pb}$ but similar $\mathrm{Nd}$ isotope ratios ${ }^{27}$ to the Gough volcanic rocks. Surprisingly, no samples plot within the Tristan field. If only flood basalts that do not show clear signs of contamination in ${ }^{87} \mathrm{Sr} /{ }^{86} \mathrm{Sr}$ (defined as ${ }^{87} \mathrm{Sr} /{ }^{86} \mathrm{Sr}<0.7067$ because 0.7067 is the highest value in the oceanic hotspot track) are considered on the uranogenic $\mathrm{Pb}$ isotope diagram, they only show a slightly greater range than the Gough field, which may reflect slight $\mathrm{Pb}$-isotopic contamination from the continental crust. The similarity in $\mathrm{Pb}$-isotopic composition between the flood basalts with low ${ }^{87} \mathrm{Sr} /{ }^{86} \mathrm{Sr}$ and the oceanic Gough domain is consistent with the initial plume material having primarily had a Goughtype composition. In summary, Parana-Etendeka samples that show no obvious signs of being contaminated within the continental lithosphere plot within the Gough domain without any evidence for the presence of Tristan-type compositions in their source.

\section{Discussion}

Now we will evaluate possible models for explaining the origin of the Tristan and Gough domains and geochemical evolution of the Tristan-Gough hotspot. On the ${ }^{87} \mathrm{Sr} /{ }^{86} \mathrm{Sr}$ versus ${ }^{143} \mathrm{Nd} /{ }^{144} \mathrm{Nd}$, ${ }^{143} \mathrm{Nd} /{ }^{144} \mathrm{Nd}$ versus ${ }^{176} \mathrm{Hf} /{ }^{177} \mathrm{Hf}$, and the ${ }^{206} \mathrm{~Pb} /{ }^{204} \mathrm{~Pb}$ versus ${ }^{207} \mathrm{~Pb} /{ }^{204} \mathrm{~Pb},{ }^{87} \mathrm{Sr} /{ }^{86} \mathrm{Sr},{ }^{143} \mathrm{Nd} /{ }^{144} \mathrm{Nd}$ and ${ }^{176} \mathrm{Hf} /{ }^{177} \mathrm{Hf}$ isotope correlation diagrams (see ref.13, Figs $2 \mathrm{a}$ and 4 and Supplementary Fig. 2), the Tristan domain falls between the Gough and Atlantic MORB fields, suggesting interaction between a Gough-type plume and depleted upper mantle to generate the Tristan domain $^{13}$. If this were the case, however, the Tristan domain would also have to be shifted towards the Atlantic MORB field on the thorogenic $\mathrm{Pb}$ isotope diagram (Fig. 2b), since the denominator of the plotted ratios is the same element. Instead the Tristan domain almost completely overlaps the Gough domain and both are distinct from Atlantic MORB, in stark contrast to the nearly complete separation of the domains on the uranogenic $\mathrm{Pb}$ isotope diagram on which the Tristan domain overlaps the Atlantic MORB field (Fig. 2a). Therefore, despite being generally more geochemically depleted in composition than the Gough domain, the Tristan domain cannot simply be derived through mixing of a Gough source and upper MORB-source mantle. Consequentially, we attribute both compositional types to the Tristan-Gough plume, implying a deep source for both.

To evaluate the origin of plume zonation, a fundamental question concerns the distribution of both compositional types in the Tristan-Gough plume. Is the plume chemically zoned with distinct Tristan and Gough domains ${ }^{13}$ or are these components uniformly distributed throughout the plume but sampled by different extents of melting, for example, under lithosphere with different thicknesses ${ }^{32-34}$ ? In particular, was the Tristan composition also present in the early plume $(\sim 70-132 \mathrm{Ma})$, but simply not sampled? Picritic and tholeiitic flood basalts, generated during the initial plume-head stage of volcanism, are typically associated with high temperatures and thus high degrees of melting (commonly 20-30\%) ${ }^{35}$ even in continental settings ${ }^{35,36}$. Therefore, the Etendeka and Parana flood basalts should have preferentially sampled the more depleted (or less enriched) Tristan component, if it were present. Even if the Tristan component was somehow more fertile (despite being more depleted isotopically), the lower-degree alkalic melts (alkali basalts, basanites and nephelinites) associated with the flood basalt volcanism should have sampled the more fertile component, if both components had been present. Since so far only Gough compositions have been identified in the flood basalts, despite the large range in rock types reflecting a large range of melting conditions, the plume head is likely to have primarily had a Gough-type composition.

Although temperatures may have been lower during the formation of the early hotspot track from the plume stem than during the plume-head stage, the early-plume stem was located beneath the mid-Atlantic ridge, allowing upwelling to shallower depths and greater extents of pressure-release melting than possible beneath continental lithosphere. This situation should also have favoured melting of the more depleted Tristan component if it had been present in the plume. Certainly compared with the later, intraplate history of the hotspot $(<60 \mathrm{Ma})$, degrees of melting should have been higher during melting of the early plume stem. Ratios of more to less incompatible trace elements (for example, $\mathrm{La} / \mathrm{Sm}$, which is relatively insensitive to differentiation except in highly evolved rocks) are inversely proportional to the melt fraction. Therefore, if lithospheric thickness controls the extent of melting, the $\mathrm{La} / \mathrm{Sm}$ ratio should have been lower when the plume was ridge-centred and should have increased as the plume became progressively more intraplate after $\sim 60 \mathrm{Ma}$. As expected, the $\mathrm{La} / \mathrm{Sm}$ ratio 

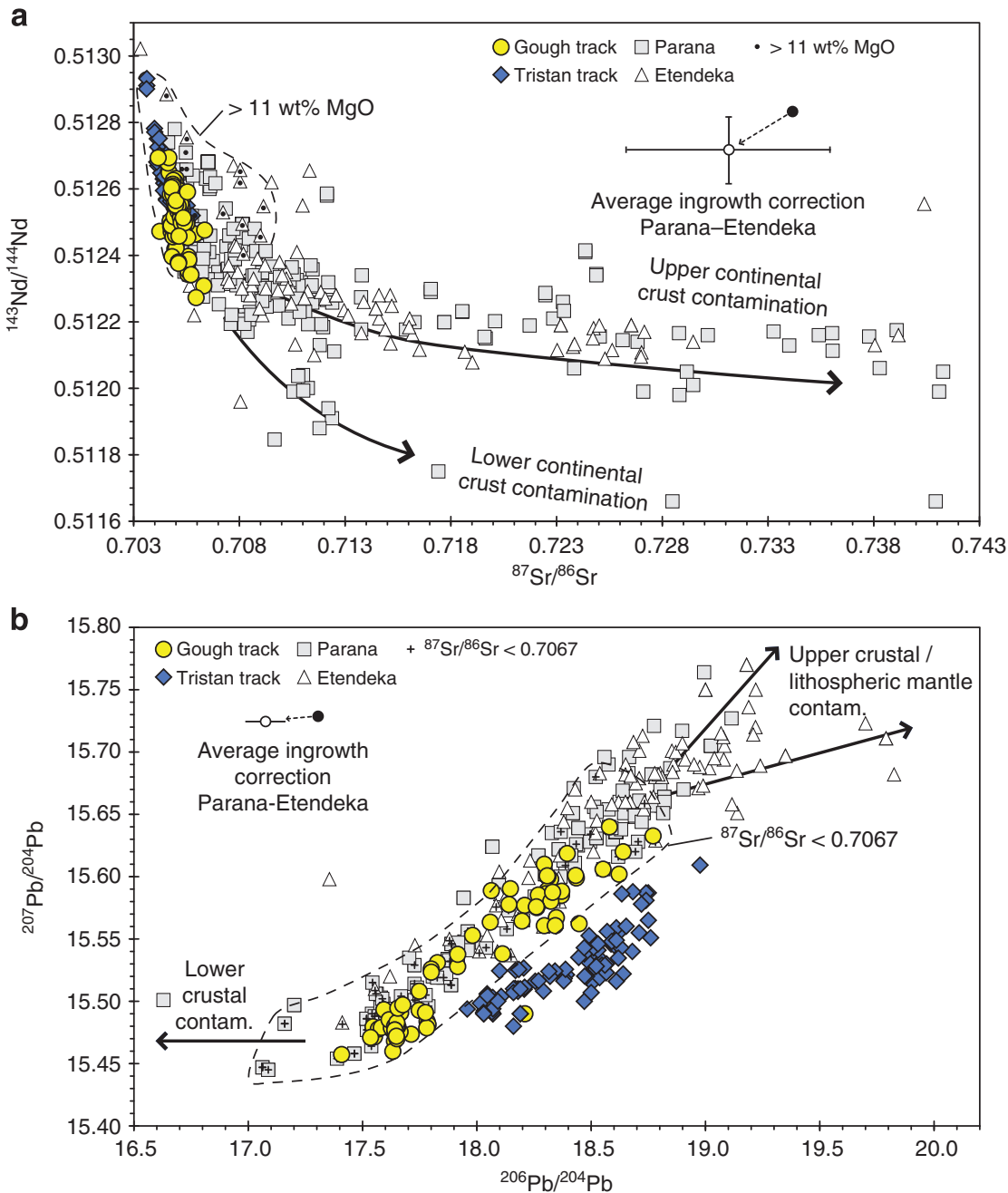

Figure 4 | Larger range in isotopic composition of the continental flood volcanism most likely reflects continental lithospheric contamination. The range in isotopic composition of continental flood volcanism and Tristan-Gough oceanic hotspot track volcanism are shown on (a) ${ }^{87} \mathrm{Sr} /{ }^{86} \mathrm{Sr}$ versus ${ }^{143} \mathrm{Nd} /$ ${ }^{144} \mathrm{Nd}$ and (b) ${ }^{206} \mathrm{~Pb} /{ }^{204} \mathrm{~Pb}$ versus ${ }^{207} \mathrm{~Pb} /{ }^{204} \mathrm{~Pb}$ isotope correlation diagrams. In (a) samples with $\mathrm{MgO}>11$ wt.\% (enclosed within dashed line) show a much more restricted range in isotopic composition, yet ${ }^{87} \mathrm{Sr} /{ }^{86} \mathrm{Sr}$ ratio in some mafic samples is still higher than in the oceanic part of the hotspot track, either reflecting contamination by crustal material or lithospheric mantle, both of which can have extremely radiogenic $\mathrm{Sr}^{27,28}$. In (b), if only Etendeka and Parana flood basalts with ${ }^{87} \mathrm{Sr} /{ }^{86} \mathrm{Sr}<0.7067$ (highest value in the oceanic hotspot track) are considered on the uranogenic Pb isotope diagram (marked with a cross and enclosed within the field defined by the dashed line), they only show a slightly greater range than the Gough field, suggesting that ${ }^{87} \mathrm{Sr} /$ ${ }^{86} \mathrm{Sr}$ ratio can be used to effectively filter for continental lithospheric contamination. Arrows denote directions for upper and lower crustal and/or lithospheric mantle contamination. In (a) the arrow labelled 'Upper continental crust contamination' extends into the field for Damara S-type granites and points to the field for Damara metasediments ${ }^{27}$. The arrow labelled 'Lower continental crust contamination' points toward the Kaokoland gneisses (PreDamara basement) ${ }^{27}$. In (b) the 'Lower crustal contam. (contamination)' arrow overlaps with and points to lower crustal granulites from the NamaquaNatal Belt in South Africa ${ }^{28}$. The 'Upper crustal/lithospheric mantle contamination' arrows point to the following rock groups in Namibia: (1) upper arrowKhan granodiorites (samples G12 and G13 (ref. 30) and 02/99 and 03/99 (ref. 31)) and (2) lower arrow-Kuiseb schists (sample Kh27 (ref. 30 )) and lithospheric mantle, estimated to have a present-day composition of ${ }^{206} \mathrm{~Pb} /{ }^{204} \mathrm{~Pb} \sim 19.8$ and ${ }^{207} \mathrm{~Pb} /{ }^{204} \mathrm{~Pb} \sim 15.7$ (based on sample VB32) beneath the Spitzkoppe region in Namibia ${ }^{27}$. See Supplementary Dataset 5 and additional data from GEOROC (http://georoc.mpch-mainz.gwdg.de/georoc/). Average radiogenic ingrowth correction and $1 \sigma$ variation for Parana and Etendeka as defined in the Fig. 3 caption.

shows a very crude overall increase with decreasing age along the hotspot track (Supplementary Fig. 3), consistent with higher degrees of melting while the plume was ridge-centred. As noted previously, higher degrees of melting should have favoured melting of the more depleted Tristan component if it had been present in the plume during its earlier ( $\sim 70-120 \mathrm{Ma})$ history. Finally, parental magma types range from tholeiite to alkali basalt on the Walvis Ridge and Rio Grande Rise. Therefore, if both Tristan and Gough components were present in the early plume stem $(\sim 70-120 \mathrm{Ma})$, it is likely that both would have been sampled regardless of which was more fertile ${ }^{37,38}$. Since none of the samples older than $70 \mathrm{Ma}$ have clear Tristan-type compositions, we do not believe that the Tristan component, if present at all, was abundant in the early plume.

Over the last $\sim 70 \mathrm{Myr}$, the hotspot track consisted of distinct Tristan and Gough compositional geographic domains with the northwestern portion of the hotspot track (going to Tristan da Cunha Island) consisting of Tristan-type compositions and the southeastern part of the track (going to Gough Island) consisting of Gough-type compositions ${ }^{13}$ (Fig. 1). The first known occurrence of Tristan-type lavas occurred near the SW end of the Walvis ridge when the hotspot was still ridge centred. After 
$\sim 60 \mathrm{Ma}$, the plume became intraplate and the lithosphere overlying the hotspot generally became thicker with decreasing age ${ }^{13}$. Since the temporal variations in lithospheric thickness over the last $70 \mathrm{Myr}$ far outweigh the spatial differences in the lithospheric thickness between the Tristan and Gough subtracks at any given time, we would expect a temporal rather than a spatial change in isotopic composition. We, however, do not see a shift in isotopic composition from one type of component to the other with age, but rather see a spatial separation throughout the last $70 \mathrm{Myr}$ of the hotspot's history. Although minor compared with the changes in lithospheric thickness with age, the Tristan track was located slightly closer to the Mid-Atlantic ridge during its formation and thus on slightly younger and thinner crust than the Gough track, which suggests that it may have formed through higher degrees of melting. If this were the case, we would expect more to less incompatible element ratios to be systematically lower in the Tristan lavas than in the Gough lavas. The $\mathrm{La} / \mathrm{Sm}$ ratios of the lavas from the two subtracks, however, largely overlap at any given time or position along the hotspot track (Supplementary Fig. 3), suggesting that potential differences in lithospheric thickness between the two domains did not lead to a systematic difference in degree of melting. This is not surprising since the fractionated and overlapping heavy rare earth element patterns in both the Tristan and Gough lavas ${ }^{13}$ suggest that garnet was a residual phase during melting for both compositional types, and thus melting was likely to be well below the depths affected by the thickness of young lithosphere. In summary, since the isotopic composition of the erupted lavas does not appear to be related to differences in melting conditions and extent, we conclude that the plume primarily contained a Gough-type compositional range during its early history with a Tristan vertical compositional zone or stripe ${ }^{39,40}$ appearing on its northwestern side $\sim 70 \mathrm{Ma}$ (ref. 13). Thereafter the plume remained bilaterally zoned. Below we discuss models to explain how a plume with relatively uniform composition turned into a zoned plume half way through its lifetime.

Although previous models have favoured the base of the lower mantle to be the source of plume zonation ${ }^{6,8-10,12,13}$, we will first consider mid-mantle origins for the compositional variation. Plumes, for example, could entrain a sheath of depleted MORBlike material when they pass through the upper-lower mantle transition $z o n e^{41,42}$. Thus, we must pose the question as to whether the Tristan component could have been picked up in the transition zone. In material with a strongly temperaturedependent viscosity like the earth's mantle, however, laboratory and numerical experiments suggest much smaller amounts of entrainment than for thermal plumes in an isoviscous fluid ${ }^{40}$. Seismic imaging of examples of apparent plume broadening beneath $660 \mathrm{~km}$ suggests that there may be a higher viscosity transition zone ${ }^{43}$. This type of radial mantle viscosity structure, however, was also found to be associated with limited entrainment ${ }^{40}$. Furthermore, the high ${ }^{208} \mathrm{~Pb} /{ }^{204} \mathrm{~Pb}$ of the Tristan component distinguishes it from depleted upper mantle and it is hard to explain why an entrained sheath of material around the entire plume would only be sampled by melting on the plume's NW side, in particular when the plume was intraplate. Perhaps stalled slabs could be distributed irregularly in the transition zone, so that the plume may only have entrained such material on its NW side ${ }^{44}$. Recycled ocean crust is commonly believed to have a high time-integrated $\mathrm{U} / \mathrm{Pb}$ ratio generating radiogenic ${ }^{206} \mathrm{~Pb} /{ }^{204} \mathrm{~Pb}$ at relatively unradiogenic ${ }^{208} \mathrm{~Pb} / 204 \mathrm{~Pb}$ over time and thus plotting beneath an extension of the MORB field ${ }^{26}$. The Gough and Tristan components, however, have relatively low ${ }^{206} \mathrm{~Pb} /{ }^{204} \mathrm{~Pb}$ and high ${ }^{208} \mathrm{~Pb} /{ }^{204} \mathrm{~Pb}$ and plot above the MORB field on the thorogenic $\mathrm{Pb}$ isotope diagram. In conclusion, mid-mantle entrainment models do not appear to be able to adequately explain the zonation of the Tristan-Gough plume.

We propose the following model to explain the observed temporal and spatial changes in geochemistry of the TristanGough hotspot track (Fig. 5). Both analogue ${ }^{40}$ and numerical ${ }^{39,40,45}$ experiments suggest that thermal plumes and starting plumes in the mantle will primarily consist of material from their basal boundary layer. According to plate motion reconstructions, the original eruption site of the Parana-Etendeka flood basalts lies vertically above and well within $(\sim 1,000 \mathrm{~km})$ the western edge of the African LLSVP, defined by the $1 \%$ slow shearwave velocity contour ${ }^{20,21}$. The Tristan-Gough plume head is therefore likely to have been derived from the African LLSVP and, as dynamic plumes are near-vertical flow structures, its base will have sampled this region, consistent with this part of the LLSVP having a Gough-type source composition. In contrast, in these reconstructions the present Tristan-Gough hotspot is located south-southwest of the reconstructed flood basalt source region so that it now almost directly overlies the boundary of the African LLSVP. If these reconstructions are correct, the change in location could reflect migration of the plume stem towards the margin of the LLSVP after the initial plume head event at an average relative speed of $\sim 1,000 \mathrm{~km}$ per $100 \mathrm{Myr}$ or $\sim 1 \mathrm{~cm}$ per year. This scenario implies that both plume stem locations and the boundary of the LLVSP can slowly drift due to slow deep mantle flow ${ }^{46}$ moving at speeds of $\sim 1-10 \mathrm{~mm}$ per year, $<10 \%$ of typical speeds of surface plate motions. Alternatively, the base of the plume may have remained fixed in location throughout its early history. In this case, the plume may have exhausted the Gough material between the plume base and the margin of the LLSVP at $\sim 70 \mathrm{Ma}$, sucking the LLSVP boundary into the base of the plume. A similar model has been proposed to explain the appearance of the Loa stripe in the Hawaiian plume, in which the Hawaiian plume draws in mantle from the Pacific LLSVP (Fig. 5) ${ }^{47}$. The appearance of Tristan-type compositions at $\sim 70 \mathrm{Ma}$ in the Tristan-Gough hotspot track suggest that the boundary of the Atlantic LLSVP was drawn into the base of the plume at a northeastern (NE)-SW orientation, resulting in a bilaterally zoned plume assuming laminar flow in the plume conduit ${ }^{6,39,40,45,47,48}$. For largely NE-SW absolute plate motions, surface geochemical zonation is predicted by numerical experiments to form in a NE-SW direction, reflecting the inflow pattern at the base of the plume stem ${ }^{47}$. Since plume material is thought to rise within the stem at speeds $>1 \mathrm{~m}$ per year (refs 46,49 ), it would have taken $<3 \mathrm{Myr}$ for Tristan-type mantle to appear in the hotspot melts after this component entered the plume stem. Over the last $\sim 70 \mathrm{Myr}$, the distance between the Tristan and Gough subtracks has progressively increased, which could reflect progressive bifurcation of a plume that roughly split along its compositional boundary ${ }^{24}$. In addition, the Tristan subtrack has become a progressively more prominent volcanic feature (in respect to erupted volume) than the Gough subtrack, suggesting that the intake of Gough-type material in the TristanGough plume has systematically diminished at the expense of the Tristan-type material with decreasing age. If this trend continues, Gough material could also be exhausted from the southeastern side of the plume source in the future, such that the plume becomes entirely Tristan-like in composition. This model demonstrates how plume zonation can develop and also disappear, accompanied by an overall change in the composition of the plume from before to after its zoned history.

In contrast to this postulated evolution for the Tristan-Gough hotspot track, the Hawaiian hotspot track is not associated with a known large igneous province or flood basalt event at its initiation, and we only have the geologic record of a long-lived plume tail. The Loa component, presumably derived from the 
Pacific LLSVP 9,10 , is absent in the Emperor Seamounts and older accreted Hawaiian complexes in Kamchatka, with only the Kea component being present in the earlier history of the hotspot ${ }^{17}$. Thus far, the Loa component has primarily been found in the Hawaiian Islands $8,9,10,17$, but sufficient data are not available to evaluate its presence in the Hawaiian Seamounts. If the Hawaiian plume was located near to but outside of the Pacific LLSVP, it could have sucked in LLSVP material with time ${ }^{47}$. This is a potential explanation for the significant increase in Hawaiian plume output (crustal volume flux) observed in the bathymetry and residual gravity anomalies beginning at $\geq 15 \mathrm{Ma}$ with a

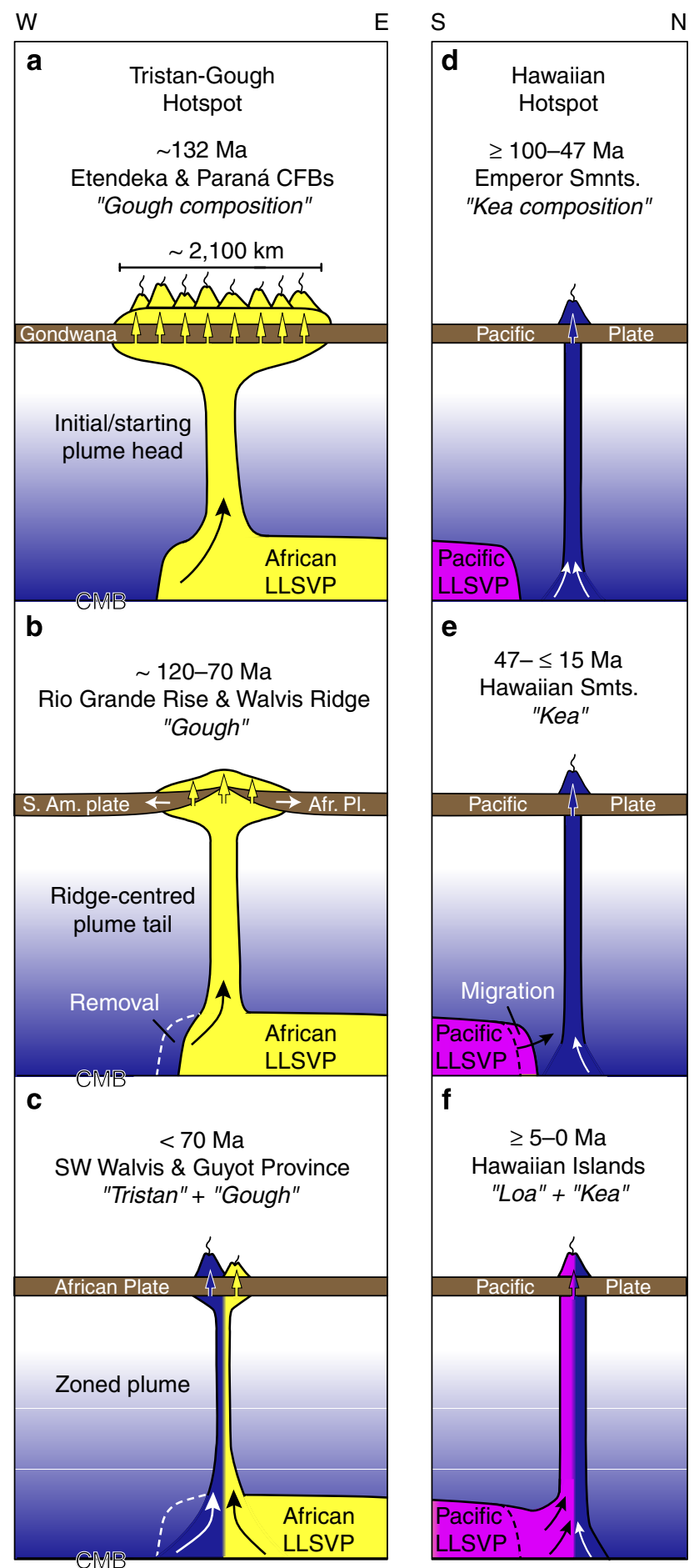

further marked increase at $\sim 7 \mathrm{Ma}$ (ref. 50), although passage of fracture zones bounding lithosphere of different ages/thicknesses over the hotspot no doubt also contributed to changes in volcanic flux ${ }^{51}$. In conclusion, while plumes appear to form near the boundaries of the LLSVPs ${ }^{20,21}$, plume stems may form or migrate to either side of LLSVP boundaries or, alternatively, remain stationary and pull in a migrating boundary of a LLSVP. Both situations would lead to a compositionally zoned plume. Tapping of LLSVP material, if it is hotter and/or more fertile than surrounding ambient deep mantle, would lead to an increase in productivity of the plume, whereas tapping of more depleted and/ or colder ambient mantle at the margin of a LLSVP would lead to a decrease in plume magma productivity. This scenario lends further support to the paradigm that plumes are long-lived upwelling structures within the convecting mantle, flow features that can persist despite a change in their source material. If so, there is the potential to further use geochemical evolution along other long-lived plume tracks to map the space-time variation of mantle composition near the core-mantle boundary.

\section{Methods}

Overview. Sixty dredge and drill core samples were analysed for major and trace elements and forty-one of them for $\mathrm{Sr}-\mathrm{Nd}-\mathrm{Hf}-\mathrm{Pb} \mathrm{DS}$ isotope ratios in the framework of this study. A full table with all analytical data and sample information is provided in Supplementary Dataset 1.

Sampling. The samples were obtained from several repositories and were originally recovered during the US American cruises RC11 and RC16 (R/V Robert D. Conrad) in 1967 and 1972, the CIRCE cruise (R/V Argo) in 1968, cruise VM 29 (R/V Vema) in 1972, cruise AII-93 (R/V Atlantis II) in 1975, during the French cruise (WALDA-002) CH19 (R/V Jean Charcot) in 1971, during a Russian cruise with the R/V Akademik Kurchatov in 1975, during cruise 51 of the South African ship R/V S.A.Agulhas, during DSDP Legs 72 (Site 516F), 74 (Sites 525A, 527 and 528) with the R/V Glomar Challenger in 1980 and during German expeditions with the R/V Polarstern (ANT-XXIII-5 (PS69)) in 2006 and the R/V Sonne (SO233) in 2014. Forty samples are from sites located along the Walvis Ridge, including dredge samples from the northern flank at its northeastern-most end close to the Namibian coast and from the southern flank of the southwestern part, from DSDP Sites 525A, 527 and 528, which form a transect across the southwestern end of the Walvis Ridge. Nine samples were obtained from the Rio Grande Rise on which isotope analyses were carried out on five. These include two dredge sites at the border of a northwest-southeast trending canyon that cuts the Western Rio Grande Rise and from DSDP Site 516F on the main platform of the Rio Grande Rise. We

Figure 5 | Models illustrating the geochemical evolution of the TristanGough and Hawaiian hotspots. (a) For the Tristan-Gough hotspot, the plume head is derived from the inner margin of the African low shear-wave velocity province (LLSVP) with enriched Gough composition. (b) The early plume stem continues to tap only LLSVP, but the margin of the LLSVP is continually drawn closer to the plume stem and/or the plume stem migrates towards the LLSVP boundary. (c) At $\sim 70 \mathrm{Ma}$, the LLSVP material on the northeastern side of the plume conduit is exhausted or the base of the plume may have migrated to the LLSVP boundary, so that depleted Tristan material from outside the LLSVP is also drawn into the plume conduit resulting in a zoned plume. (d) There is no geological evidence for the initiation of the Hawaiian plume. The oldest volcanic rocks associated with the hotspot are from $\sim 100$ Myr old seamounts accreted to the forearc in Kamchatka ${ }^{17}$. The Hawaiian plume originally only taps the ambient depleted lower mantle (Kea component) between $~ 100-47 \mathrm{Ma}$. (e) At some time between 45 and $5 \mathrm{Ma}$ (most likely between $\geq 15$ and $7 \mathrm{Ma}$ when there was a peak in volcanic flux from the Hawaiian plume), enriched Loa material is drawn into the Hawaiian plume from the Pacific LLSVP (which has a distinct composition from the African LLSVP) and the plume becomes zoned. (f) After $\geq 15-5 \mathrm{Ma}$ the Hawaiian Plume has remained zoned. S. Am., South American; Afr. Pl., African plate; CMB, core-mantle boundary. Profiles are not to scale. No distinction has been made between the thickness of oceanic and continental lithosphere. 
also analysed ten additional primarily evolved dredge samples from the Gough subtrack and one from the Tristan subtrack within the Guyot Province.

Sample preparation. For the geochemical analyses only the least altered inner parts of the selected rock samples were used to prepare rock chips and powders. After initial jaw-crushing, the rock chips were sieved (fractions: $<0.25,0.25-0.5$, $0.5-1,1-2,2-4$ and $>4 \mathrm{~mm}$ ) and thereafter repeatedly cleaned in an ultrasonic bath with deionized water for $\sim 20-30$ min until a clear solution was obtained. The freshest chips were then hand-picked under a binocular microscope. About 5-10 g of 1- to 4-mm-sized whole-rock chips were taken to prepare bulk rock powders (in an agate mortar and agate ball-mill) for major and trace element and $\mathrm{Sr}-\mathrm{Hf}$ isotope analyses. In addition, $500 \mathrm{mg}$ of whole-rock chips $(0.5-1 \mathrm{~mm}$ fraction) was picked under a binocular microscope for $\mathrm{Sr}-\mathrm{Nd}-\mathrm{Pb}$ isotope analyses.

Major element analyses. Major elements were determined by X-Ray Fluorescence Analysis (XRF) at GEOMAR Helmholtz Centre for Ocean Research Kiel (using a Philips X'Unique PW 1480 X-ray florescence spectrometer), at the Institute of Mineralogy and Petrography at the University of Hamburg (using a Magix Pro PW 2540 XRF) and by inductively coupled plasma emission spectroscopy in the Acme Analytical Laboratories in Vancouver. Eleven international rock standards were measured along with the samples (JA-2, JA-3, JB-2, JB-3, JG-2, JG-3, JGB-1, JR-1, AGV-2, BIR-1, BHVO-2 and BCR-2). Results and information about data quality are presented in Supplementary Dataset 2.

Trace element analyses. Trace element analyses were carried out on an AGILENT 7500cs inductively coupled plasma mass spectrometer at the Institute of Geosciences at the Christian-Albrechts-University of Kiel after the methods of ref. 52 and the Acme Analytical Laboratories in Vancouver by inductively coupled plasma mass spectrometry (ICP-MS) subsequent to a lithium metaborate/ tetraborate fusion and nitric acid dissolution as well as an aqua regia digestion. BIR-1, BHVO-2, BCR-2 and AGV-2 were analysed as geochemical reference materials. Results and information about data quality are given in Supplementary Data set 3 (University Kiel) and Supplementary Data set 4 (Acme).

Isotope analyses. $\mathrm{Sr}-\mathrm{Nd}-\mathrm{Pb}-\mathrm{Hf}$ isotope analyses were carried out at GEOMAR Helmholtz Centre for Ocean Research Kiel by thermal ionization mass spectrometry $(\mathrm{Sr}-\mathrm{Nd}-\mathrm{Pb}$ ) and multi-collector ICP-MS (Hf) in static multi-collector mode on both types of instruments. Between 100 and $250 \mathrm{mg}$ of sample chips were leached in $2 \mathrm{~N} \mathrm{HCl}$ at $70^{\circ} \mathrm{C}$ for $1 \mathrm{~h}$ and subsequently triple rinsed in $18 \mathrm{M} \Omega$ water before digestion. For each sample additional $\mathrm{Sr}$ isotope analyses were generated on $100 \mathrm{mg}$ of leached powders $\left(6 \mathrm{~N} \mathrm{HCl}\right.$ at $150^{\circ} \mathrm{C}$ for 3 days $)$ to remove possible seawater alteration effects more thoroughly. Ion chromatography followed established standard procedures ${ }^{53,54}$. $\mathrm{Pb}$ and most $\mathrm{Sr}$ isotope analyses were performed on a Finnigan MAT $262 \mathrm{RPQ}^{2+}$ while $\mathrm{Nd}$ and the remaining $\mathrm{Sr}$ isotope analyses were determined on a Thermo Fisher TRITON thermal ionization mass spectrometer. $\mathrm{Nd}$ and $\mathrm{Sr}$ ratios were normalized within run to ${ }^{146} \mathrm{Nd} /$ ${ }^{144} \mathrm{Nd}=0.7219$ and ${ }^{86} \mathrm{Sr} /{ }^{88} \mathrm{Sr}=0.1194$, respectively. Total chemistry blanks were below 150 p.g. for both elements and thus negligible. Sample data are reported relative to ${ }^{87} \mathrm{Sr} /{ }^{86} \mathrm{Sr}=0.710250 \pm 0.000013(n=42 ; 2 \sigma$ external reproducibility) for NBS987 on the MAT262 $\mathrm{RPQ}^{2+}$ and ${ }^{87} \mathrm{Sr} /{ }^{86} \mathrm{Sr}=0.710250 \pm 0.000013(n=5 ; 2 \sigma$ external reproducibility) on the TRITON. Nd sample data are reported relative to ${ }^{143} \mathrm{Nd} /{ }^{144} \mathrm{Nd}=0.511850 \pm 0.000007(n=25 ; 2 \sigma$ external reproducibility) for $\mathrm{La}$ Jolla and our in-house SPEX Nd monitor ${ }^{143} \mathrm{Nd} /{ }^{144} \mathrm{Nd}=0.511715 \pm 0.000005$ $(n=13 ; 2 \sigma$ external reproducibility). $\mathrm{Pb}$ mass bias correction followed the DS technique $^{55}$. DS-corrected values for NBS981 are ${ }^{206} \mathrm{~Pb} /{ }^{204} \mathrm{~Pb}=16.9416 \pm 0.0024$, ${ }^{207} \mathrm{~Pb} /{ }^{204} \mathrm{~Pb}=15.4992 \pm 0.0024$ and ${ }^{208} \mathrm{~Pb} / 204 \mathrm{~Pb}=36.7246 \pm 0.0061 \quad(n=18 ; 2 \sigma$ external reproducibility) and compare well with published double- and triple-spike data $^{56-60}$. Total chemistry blanks were $10-40$ p.g. for $\mathrm{Pb}$ and thus negligible. Hf chemistry followed the two-column procedure ${ }^{61}$ using unleached powders, and analyses were carried out on a VG Axiom MC-ICPMS and on a Nu plasma MCICPMS. Within-run mass bias correction used for ${ }^{179} \mathrm{Hf} /{ }^{177} \mathrm{Hf}$ was 0.7325 . Total chemistry blanks were between 60 and 150 p.g. Hf. Our in-house SPEX Hf ICP standard solution (Lot no.9) was calibrated to JMC $475\left({ }^{176} \mathrm{Hf} /{ }^{177} \mathrm{Hf}=0.282163\right.$ (ref. 61)) and gave an average standard bracketing normalized ratio of ${ }^{176} \mathrm{Hf} /$ ${ }^{177} \mathrm{Hf}=0.282173 \pm 0.000008(n=132 ; 2 \sigma$ external reproducibility; VG Axiom MCICPMS $)$ and $0.282170 \pm 0.000004(n=48 ; 2 \sigma$ external reproducibility; Nu plasma MC-ICPMS). Furthermore, USGS reference material BHVO-2 gave ${ }^{176} \mathrm{Hf} /{ }^{177} \mathrm{Hf}=$ 0.283107 , which compares well with the mean of compiled values at GEOREM $\left({ }^{176} \mathrm{Hf} /{ }^{177} \mathrm{Hf}=0.283109 \pm 0.000012\right.$; http://georem.mpch-mainz.gwdg.de/).

Evaluation of isotope replicate analyses. Replicate analyses for $\mathrm{Sr}-\mathrm{Nd}-\mathrm{Pb}$ isotopes were carried out on a second sample digestion for five samples. Whole-rock chips were leached with warm $2 \mathrm{~N} \mathrm{HCl}$ and powders with hot $6 \mathrm{~N} \mathrm{HCl}$ as described above. While the reproducibility of ${ }^{143} \mathrm{Nd} /{ }^{144} \mathrm{Nd}$ lies within (three samples) or very close (two samples) to the external $2 \sigma$ errors of the standards, offsets outside the external $2 \sigma$ array of the standards are observed for radiogenic $\mathrm{Sr}$ and $\mathrm{Pb}$ isotope ratios on leached chips. In detail DSDP Leg $74528421 \mathrm{~W} 29-45$ lies slightly outside the external errors while a larger offset is observed for PS69/424-1-DR
26-1. The somewhat limited reproducibility for Sr on leached whole-rock chips is ascribed to variable degrees of seawater alteration even in visually homogeneoussample chips and the inability of the leaching reagent to fully penetrate the sample and thus remove all $\mathrm{Sr}$ introduced through secondary processes. Notably, strong leaching of powders does not always yield the least radiogenic ${ }^{87} \mathrm{Sr} /{ }^{86} \mathrm{Sr}$ when compared with the corresponding data of the leached chips. Therefore, the least radiogenic ${ }^{87} \mathrm{Sr} /{ }^{86} \mathrm{Sr}$ of each sample is plotted and displayed in Table 1 of the manuscript, since it is presumably closest to the pristine magmatic value. $\mathrm{Pb}$ isotope ratios are reproduced within the external $2 \sigma$ errors for NBS981 for four out of five samples in ${ }^{207} \mathrm{~Pb} /{ }^{204} \mathrm{~Pb}$ and three samples in ${ }^{208} \mathrm{~Pb} /{ }^{204} \mathrm{~Pb}$, while ${ }^{206} \mathrm{~Pb} /{ }^{204} \mathrm{~Pb}$ is reproduced for only one sample under these specifications. Interaction with seawater during low temperature alteration and seafloor weathering can lead to a heterogeneous enrichment of uranium that causes variable degrees of ${ }^{206} \mathrm{~Pb}$ ingrowth over time scales relevant in this paper. In this respect it is worth noting that ${ }^{207} \mathrm{~Pb} /{ }^{204} \mathrm{~Pb}$ is less affected by secondary $\mathrm{U}$ enrichment as ${ }^{235} \mathrm{U}$ is 137.88 times less abundant than ${ }^{238} \mathrm{U}$ presently. The two samples for which ${ }^{208} \mathrm{~Pb} /{ }^{204} \mathrm{~Pb}$ did not reproduce within the external $2 \sigma$ error of NBS981 appear to have undergone a more complex alteration history that includes $\mathrm{Pb}$ removal at high temperatures in addition to $\mathrm{U}$ enrichment at low temperatures. The slight variations caused by alteration, however, do not affect the overall scientific interpretations and conclusions derived from the $\mathrm{Sr}$ and $\mathrm{Pb}$ isotope data. Replicate $\mathrm{Hf}$ analyses on sample DSDP Leg 74 525A $575 \mathrm{~W}$ 141-148 agreed within the external $2 \sigma$ errors of the standard.

\section{References}

1. Vanderkluysen, L. et al. Louisville Seamount Chain: Petrogenetic processes and geochemical evolution of the mantle source. Geochem. Geophys. Geosyst. 15, 2380-2400 (2014).

2. Frey, F. A. \& Weis, D. Temporal evolution of the Kerguelen plume: geochemical evidence from 38 to 82 ma lavas forming the Ninetyeast ridge. Contrib. Mineral. Petrol. 121, 12-28 (1995).

3. Class, C., Goldstein, S. L. \& Galer, S. J. G. Discussion of 'Temporal evolution of the Kerguelen plume: geochemical evidence from $\sim 38$ to $82 \mathrm{Ma}$ lavas forming the Ninetyeast Ridge' by F.A. Frey and D. Weis. Contrib. Mineral. Petrol. 124, 98-103 (1996)

4. Geldmacher, J. et al. Hafnium isotopic variations in volcanic rocks from the Caribbean Large Igneous Province and Galápagos hot spot tracks. Geochem. Geophys. Geosyst. doi:10.1029/2002GC0004774 (2003).

5. Harpp, K. S., Wanless, V. D., Otto, R. H., Hoernle, K. A. J. \& Werner, R. The Cocos and Carnegie Aseismic Ridges: a trace element record of long-term plume-spreading center interaction. J. Petrol. 46, 109-133 (2005).

6. Hoernle, K. et al. Existence of complex spatial zonation in the Galapagos plume for at least 14m.y. Geology 28, 435-438 (2000).

7. Werner, R., Hoernle, K., Barckhausen, U. \& Hauff, F. Geodynamic evolution of the Galapagos hot spot system (Central East Pacific) over the past 20m.y.: constraints from morphology, geochemistry, and magnetic anomalies. Geochem. Geophys. Geosyst 4, 1108 (2003).

8. Abouchami, W. et al. Lead isotopes reveal bilateral asymmetry and vertical continuity in the Hawaiian mantle plume. Nature 434, 851-856 (2005).

9. Weis, D., Garcia, M. O., Rhodes, J. M., Jellinek, M. \& Scoates, J. S. Role of the deep mantle in generating the compositional asymmetry of the Hawaiian mantle plume. Nat. Geosci. 4, 831-838 (2011).

10. Huang, S., Hall, P. S. \& Jackson, M. G. Geochemical zoning of volcanic chains associated with Pacific hotspots. Nat. Geosci. 4, 874-878 (2011).

11. Chauvel, C. et al. The size of plume heterogeneities constrained by Marquesas isotopic stripes. Geochem. Geophys. Geosyst. 13, Q07005 (2012).

12. Payne, J. A., Jackson, M. G. \& Hall, P. S. Parallel volcano trends and geochemical asymmetry of the Society Islands hotspot track. Geology 41, 19-22 (2013).

13. Rohde, J. et al. 70 Ma chemical zonation of the Tristan-Gough hotspot track. Geology 41, 335-338 (2013).

14. Clouard, V. \& Bonneville, A. in Plates, Plumes \& Paradigms. (eds Foulger, G. R., Natland, J. H., Presnall, D. C. \& Anderson, D. L.) (2005).

15. Guillou, H. et al. Volcanic successions in Marquesas eruptive centers: a departure from the Hawaiian model. J. Volcanol. Geotherm. Res. 276, 173-188 (2014).

16. Jackson, M. G. et al. Helium and lead isotopes reveal the geochemical geometry of the Samoan plume. Nature 514, 355-358 (2014).

17. Portnyagin, M., Savelyev, D., Hoernle, K., Hauff, F. \& Garbe-Schönberg, D. Mid-Cretaceous Hawaiian tholeiites preserved in Kamchatka. Geology 36, 903-906 (2008).

18. Richards, M. A., Duncan, R. A. \& Courtillot, V. E. Flood basalts and hot-spot tracks: plume heads and tails. Science 246, 103-107 (1989).

19. Courtillot, V., Davaille, A., Besse, J. \& Stock, J. Three distinct types of hotspots in the Earth's mantle. Earth Planet. Sci. Lett. 205, 295-308 (2003).

20. Burke, K., Steinberger, B., Torsvik, T. H. \& Smethurst, M. A. Plume generation zones at the margins of large low shear velocity provinces on the core-mantle boundary. Earth Planet. Sci. Lett. 265, 49-60 (2008). 
21. Torsvik, T. H., Smethurst, M. A., Burke, K. \& Steinberger, B. Large igneous provinces generated from the margins of the large low-velocity provinces in the deep mantle. Geophys. J. Int. 167, 1447-1460 (2006).

22. Renne, P. R., Glen, J. M., Milner, S. C. \& Duncan, A. R. Age of Etendeka flood volcanism and associated intrusions in southwestern Africa. Geology 24, 659-662 (1996).

23. Segev, A. in From continental extension to collision: Africa-Europe interaction, the Dead Sea and analogue natural laboratories. EGU Stephan Mueller Special Publication Series. (eds SAPL, Cloetingh \& Ben-Avraham, Z.) (Copernicus Publications, 2002).

24. Rohde, J. K., van den Bogaard, P., Hoernle, K., Hauff, F. \& Werner, R. Evidence for an age progression along the Tristan-Gough volcanic track from new 40Ar/ 39Ar ages on phenocryst phases. Tectonophysics 604, 60-71 (2013).

25. Richardson, S. H., Erlank, A. J., Duncan, A. R. \& Reid, D. L. Correlated Nd, Sr and $\mathrm{Pb}$ isotope variation in Walvis Ridge basalts and implications for the evolution of their mantle source. Earth Planet. Sci. Lett. 59, 327-342 (1982).

26. Zindler, A. \& Hart, S. Chemical Geodynamics. Ann. Rev. Earth Planet. Sci. 14, 493-571 (1986).

27. Thompson, R. N. et al. Origin of CFB magmatism: multi-tiered intracrustal Picrite-Rhyolite magmatic plumbing at Spitzkoppe, Western Namibia, during Early Cretaceous Etendeka magmatism. J. Petrol. 48, 1119-1154 (2007).

28. Class, C. \& le Roex, A. South Atlantic DUPAL anomaly-dynamic and compositional evidence against a recent shallow origin. Earth Planet. Sci. Lett. 305, 92-102 (2011)

29. Jung, S., Hoernes, S. \& Mezger, K. Synorogenic melting of mafic lower crust constraints from geochronology, petrology and $\mathrm{Sr}, \mathrm{Nd}, \mathrm{Pb}$ and $\mathrm{O}$ isotope geochemistry of quartz diorites (Damara orogen, Namibia). Contrib. Mineral. Petrol. 143, 551-566 (2002).

30. McDermott, F. \& Hawkesworth, C. J. Intracrustal recycling and upper-crustal evolution: A case study from the Pan-African Damara mobile belt, central Namibia. Chem. Geol. 83, 263-280 (1990).

31. Jung, S., Mezger, K. \& Hoernes, S. Petrology of basement-dominated terranes: II. Contrasting isotopic ( $\mathrm{Sr}, \mathrm{Nd}, \mathrm{Pb}$ and $\mathrm{O}$ ) signatures of basement-derived granites and constraints on the source region of granite (Damara orogen, Namibia). Chem. Geol. 199, 1-28 (2003).

32. Ballmer, M. D., Ito, G., van Hunen, J. \& Tackley, P. J. Spatial and temporal variability in Hawaiian hotspot volcanism induced by small-scale convection Nat. Geosci. 4, 457-460 (2011).

33. Prytulak, J. \& Elliott, T. TiO2 enrichment in ocean island basalts. Earth Planet. Sci. Lett. 263, 388-403 (2007).

34. Stracke, A. \& Bourdon, B. The importance of melt extraction for tracing mantle heterogeneity. Geochim. Cosmochim. Acta. 73, 218-238 (2009).

35. Fitton, J. G. \& Godard, M. in Origin and evolution of magmas on the Ontong Java Plateau. (eds Fitton, J. G., Mahoney, J. J., Wallace, P. J. \& Saunders, A. D.) (Geol. Soc. Spec. Publ.229, 2004).

36. Herzberg, C. \& Gazel, E. Petrological evidence for secular cooling in mantle plumes. Nature 458, 619-622 (2009).

37. Niu, Y., Wilson, M., Humphreys, E. R. \& O'Hara, M. J. The origin of intra-plate Ocean Island Basalts (OIB): the lid effect and its geodynamic implications. J. Petrol. 52, 1443-1468 (2011).

38. Phipps Morgan, J. Isotope topology of individual hotspot basalt arrays: mixing curves or melt extraction trajectories? Geochem. Geophys. Geosyst. 1, 1003 (2000).

39. Farnetani, C. G. \& Hofmann, A. W. Dynamics and internal structure of a lower mantle plume conduit. Earth Planet. Sci. Lett. 282, 314-322 (2009).

40. Lohmann, F. C., Hort, M. \& Morgan, J. P. Flood basalts and ocean island basalts: a deep source or shallow entrainment? Earth Planet. Sci. Lett. 284, 553-563 (2009).

41. Fitton, J. G., Saunders, A. D., Norry, M. J., Hardarson, B. S. \& Taylor, R. N. Thermal and chemical structure of the Iceland plume. Earth Planet. Sci. Lett. 153, 197-208 (1997).

42. Kempton, P. D. et al. The Iceland plume in space and time: a Sr-Nd-Pb-Hf study of the North Atlantic rifted margin. Earth Planet. Sci. Lett. 177, 255-271 (2000).

43. Nolet, G., Karato, S.-I. \& Montelli, R. Plume fluxes from seismic tomography. Earth. Planet. Sci. Lett. 248, 685-699 (2006).

44. Sigloch, K., McQuarrie, N. \& Nolet, G. Two-stage subduction history under North America inferred from multiple-frequency tomography. Nat. Geosci. 1, 458-462 (2008)

45. Farnetani, C. G. \& Hofmann, A. W. Dynamics and internal structure of the Hawaiian plume. Earth Planet. Sci. Lett. 295, 231-240 (2010).

46. Morgan, W. J. Convection plumes in the lower mantle. Nature 230, 42-43 (1971).

47. Farnetani, C. G., Hofmann, A. W. \& Class, C. How double volcanic chains sample geochemical anomalies from the lowermost mantle. Earth Planet. Sci. Lett. 359-360, 240-247 (2012).

48. Kerr, R. C. \& Mériaux, C. Structure and dynamics of sheared mantle plumes. Geochem. Geophys. Geosyst. 5, Q12009 (2004).
49. Schubert, G., Turcotte, D. L. \& Olson, P. Mantle Convection in the Earth and Planets (Cambridge Univ. Press, 2001).

50. Vidal, V. \& Bonneville, A. Variations of the Hawaiian hot spot activity revealed by variations in the magma production rate. J. Geophys. Res. 109, B03104 (2004).

51. Morgan, J. P., Morgan, W. J. \& Price, E. Hotspot melting generates both hotspot volcanism and a hotspot swell? J. Geophys. Res. 100, 8045-8062 (1995).

52. Garbe-Schönberg, C.-D. Simultaneous determination of thirty-seven trace elements in twenty-eight international rock standards by ICP-MS. Geostand. Geoanalyt. Res. 17, 81-97 (1993).

53. Hoernle, K. et al. Arc-parallel flow in the mantle wedge beneath Costa Rica and Nicaragua. Nature 451, 1094-1098 (2008).

54. Hoernle, K. \& Tilton, G. R. Sr-Nd-Pb isotope data for Fuerteventura (Canary Islands) basal complex and subaerial volcanics: applications to magma genesis and evolution. Schweiz. Mineral. Petrogr. Mitt. 71, 3-18 (1991).

55. Hoernle, K. et al. On- and off-axis chemical heterogeneities along the South Atlantic Mid-Ocean-Ridge $\left(5-11^{\circ} \mathrm{S}\right)$ : Shallow or deep recycling of ocean crust and/or intraplate volcanism? Earth Planet. Sci. Lett. 306, 86-97 (2011).

56. Baker, J., Peate, D., Waight, T. \& Meyzen, C. Pb isotopic analysis of standards and samples using a $207 \mathrm{~Pb}-204 \mathrm{~Pb}$ double spike and thallium to correct for mass bias with a double-focusing MC-ICP-MS. Chem. Geol. 211, 275-303 (2004).

57. Baker, J. A., Peate, D. W., Waight, T. E. \& Thirlwall, M. F. Reply to the: Comment on $\mathrm{Pb}$ isotopic analysis of standards and samples using a $207 \mathrm{~Pb}$ $204 \mathrm{~Pb}$ double spike and thallium to correct for mass bias with a double focusing MC-ICP-MS’ by Baker et al. Chem. Geol. 217, 175-179 (2005).

58. Galer, S. J. G. \& Abouchami, W. Practical application of lead triple spiking for correction of instrumental mass discrimination. Mineral. Mag. 62 A, 491-492 (1998).

59. Thirlwall, M. F. Inter-laboratory and other errors in $\mathrm{Pb}$ isotope analyses investigated using a ${ }^{207} \mathrm{~Pb}-{ }^{204} \mathrm{~Pb}$ double spike. Chem. Geol. 163, 299-322 (2000).

60. Thirlwall, M. F. Multicollector ICP-MS analysis of $\mathrm{Pb}$ isotopes using a ${ }^{207} \mathrm{~Pb}-{ }^{204} \mathrm{~Pb}$ double spike demonstrates up to $400 \mathrm{ppm} / \mathrm{amu}$ systematic errors in Tl-normalization. Chem. Geol. 184, 255-279 (2002).

61. Blichert-Toft, J., Chauvel, C. \& Albarède, F. Separation of Hf and Lu for highprecision isotope analysis of rock samples by magnetic sector-multiple collector ICP-MS. Contrib. Mineral. Petrol. 127, 248-260 (1997).

62. Gale, A., Dalton, C. A., Langmuir, C. H., Su, Y. \& Schilling, J.-G. The mean composition of ocean ridge basalts. Geochem. Geophys. Geosyst. 14, 489-518 (2013).

\section{Acknowledgements}

We are very grateful to the crews and funding sources of all the cruises and the Deep Sea Drilling Programme (DSDP) legs involved in obtaining samples from the Tristan-Gough hotspot track analyzed in this study. We thank S. Hauff and K. Junge for analytical support, J. Geldmacher for constructive comments, and the German Science Foundation (DFG) Priority Programme SAMPLE (grant HO1833/17-1, 2) and the German Ministry of Research and Education (BMBF; SO233-WALVIS II) for providing funding for this project. This research used samples provided by the Integrated Ocean Drilling Programme.

\section{Author contributions}

K.H., F.H. and R.W. conceived the project; K.H. was the primary interpreter of the data and writer of the paper with contributions from J.R., F.H., R.W. and J.P.M.; J.R., S.H. and F.H. generated the isotope and D.G.-S. the trace element data.

\section{Additional information}

Supplementary Information accompanies this paper at http://www.nature.com/ naturecommunications

Competing financial interests: The authors declare no competing financial interests.

Reprints and permission information is available online at http://npg.nature.com/ reprintsandpermissions/

How to cite this article: Hoernle, K. et al. How and when plume zonation appeared during the $132 \mathrm{Myr}$ evolution of the Tristan Hotspot. Nat. Commun. 6:7799 doi: $10.1038 /$ ncomms8799 (2015)

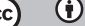

This work is licensed under a Creative Commons Attribution 4.0 International License. The images or other third party material in this article are included in the article's Creative Commons license, unless indicated otherwise in the credit line; if the material is not included under the Creative Commons license, users will need to obtain permission from the license holder to reproduce the material. To view a copy of this license, visit http://creativecommons.org/licenses/by/4.0/ 